\title{
MANEJO Y SEGUIMIENTO CLÍNICO DE PACIENTE CON SINDROME DE ALPORT FASE IV
}

Vásconez Cesar Igor ${ }^{1}$, Campoverde Alejandro Xavier ${ }^{1 *}$, Trejo Martínez Victoria ${ }^{1}$.

DOI: $10.48018 /$ rmv.v32.i1.S1

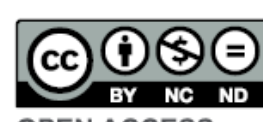

Este artículo está bajo una icencia de Creative Comnons de tipo Reconocimien- No comercial - Sin obras derivadas 4.0 International.

1.Instituto de Atención Renal Especializada IARE-CP. Quito, Ecuador.

\section{ORCID ID:}

Vásconez Cesar Igor

orcid.org/0000-0002-3591-5994

Campoverde Alejandro Xavier

orcid org/0000-0003-3387-9771

Trejo Martínez Victoria

orcid.org/0000-0001-5076-3557

* Corresponding author:

Campoverde Alejandro Xavier

E-mail: alejandrocampoverde1997@outlook.com

Article history: Manuscript presented at the I Clinical Case Contest - Hospital Vozandes Quito, February 27,2021

CARE 2017 Check List statement: The authors have real the CARE 2017 Check List and the manuscrip was prepared and revised according to the CARE 2017 Checklist..

Conflict of interest: All authors declared that there are no conflicts of interest.

Financial disclosure: The authors have no financial relationships relevant to this article to disclose.

Authors' contribution: All the authors contributed in the search, selection of articles and writing. All the authors reviewed and approved the final manuscript.

Forma de citar este artículo: Vásconez CI, Campoverde AX, Trejo V. MANEJO Y SEGUIMIENTO CLÍNICO DE PACIENTE CON SINDROME DE ALPORT FASE IV. Rev Med Vozandes. 2021; 32 (1 Suppl 1): S1-S2

\section{Resumen}

Introducción: El síndrome de Alport (SA) es una enfermedad de carácter hereditario de las membranas basales causada por mutaciones en el colágeno tipo IV. Dicha enfermedad se caracteriza por la presencia de nefropatía hereditaria progresiva asociada a sordera sensorial, así como lesiones a nivel ocular. El SA tiene una incidencia de 1 por cada 50.000 nacidos vivos, constituyendo del 1 al $2 \%$ de causa de enfermedad renal crónica (ERC) en Europa y del 3\% de ERC en la población pediátrica americana; se considera como la causa de uremia terminal en 0.6 a $4.6 \%$ de los pacientes terminales en Estados Unidos y Europa. Al momento no existe casuística al respecto en Ecuador.

En la actualidad no existe un tratamiento específico para el Síndrome de Alport, sin embargo los fármacos Inhibidores de Enzima Convertidora de Angiotensina (IECA) y los antagonistas de los receptores de angiotensina II (ARA II) han demostrado eficacia y seguridad sobre el bloqueo del sistema renina angiotensina aldosterona disminuyendo así la presencia de proteinuria y frenando el deterioro de la ERC.

Descripción del Caso: Paciente masculino de 28 años, con antecedentes personales de HTA y familiares de SA de 6 miembros: 2 sobrinos, 1 hermano y 3 sobrinas portadoras. Al examen físico se encuentra presencia de hipoacusia moderada bilateral. Presenta patología renal desde los 10 años de edad sin control adecuado. Se diagnostica Síndrome de Alport en el año 2012 por medio de biopsia renal, evidencia de hematuria y por antecedentes familiares. Actualmente se encuentra recibiendo tratamiento de Hemodiálisis en modalidad de sesión corta diaria, la cual consta de 5 sesiones semanales de lunes a viernes de 2 horas cada una; se mantiene bajo tratamiento hipotensor de $10 \mathrm{mg}$ QD de Amlodipino (Bloqueador de Canal de Calcio), y 10mg BID de Carvedilol (Beta Bloqueador), junto con 12,5mg BID de Losartán (Antagonista de los Receptores de Angiotensina II).

Se hizo un seguimiento al paciente durante todo el año 2020 hasta enero de 2021, realizando el cálculo de la Tasa de Filtración Glomerular mes por mes para poder evidenciar si existe un deterioro progresivo significativo de su función renal residual.

Conclusión: Se alude a que la función renal residual no se ha visto afectada gracias al control de la Hipertensión Arterial del paciente donde se encuentra añadido un medicamento ARA II (Losartán), el cual frena el deterioro renal progresivo que es propio del Síndrome de Alport.

La incorporación del paciente a la modalidad de sesión corta diaria de hemodiálisis ha ayudado a tener una compensación de la función renal, obteniendo una depuración continua asemejándonos a la función de un riñón sano lo más cerca que sea posible. Para que un tratamiento de hemodiálisis tenga mejores resultados compensando la función renal residual, se deben instaurar sesiones seguidas y de mayor duración, sin embargo este es un tema complicado dependiendo de la disponibilidad de tiempo y tolerancia del paciente.

Palabras clave: Síndrome de Alport, Enfermedad Renal Crónica, Hemodiálisis, Hipoacusia, Tasa de filtración glomerular. 
Keywords: Alport syndrome, Chronic Kidney

Disease, Hemodialysis, Hearing loss, Glomerular filtration rate.

\section{Abstract}

\section{MANAGEMENT AND CLINICAL FOLLOW-UP OF A PATIENT WITH ALPORT SYNDROME STAGE IV}

Introduction: Alport syndrome (AS) is a hereditary disease of the basement membranes caused by mutations in type IV collagen. This disease is characterized by the presence of progressive hereditary nephropathy associated with sensory deafness, as well as ocular lesions. AS has an incidence of 1 in every 50,000 live births, constituting 1 to $2 \%$ of the cause of chronic kidney disease (CKD) in Europe and 3\% of CKD in the American pediatric population; it is considered to be the cause of terminal uremia in 0.6 to $4.6 \%$ of terminal patients in the United States and Europe. At the moment there is no casuistry in this regard in Ecuador.

At present there is no specific treatment for Alport Syndrome, however the drugs Angiotensin Converting Enzyme Inhibitors (ACEI) and angiotensin II receptor antagonists (ARBs) have demonstrated efficacy and safety over blocking the system. renin angiotensin aldosterone, thus reducing the presence of proteinuria and slowing the deterioration of CKD.

Case description: A 28-year-old male patient with a personal history of HT and 6-member SA relatives: 2 nephews, 1 brother and 3 carrier nieces. The physical examination revealed the presence of moderate bilateral hearing loss. He presents kidney disease from the age of 10 without adequate control. Alport Syndrome was diagnosed in 2012 by means of a renal biopsy, evidence of hematuria and by family history. He is currently receiving Hemodialysis treatment in a daily short session modality, which consists of 5 weekly sessions from Monday to Friday of 2 hours each; he is kept under hypotensive treatment of 10mg QD of Amlodipine (Calcium Channel Blocker), and 10mg BID of Carvedilol (Beta Blocker), together with $12.5 \mathrm{mg}$ BID of Losartan (Angiotensin II Receptor Antagonist).

The patient was followed up throughout the year 2020 until January 2021, calculating the Glomerular Filtration Rate month by month to be able to show whether there is a significant progressive deterioration of his residual kidney function.

Conclusion: It is mentioned that the residual renal function has not been affected thanks to the control of the Arterial Hypertension of the patient where an ARA II drug (Losartan) is added, which slows the progressive renal deterioration that is typical of Alport Syndrome.

The incorporation of the patient to the modality of daily short session of hemodialysis has helped to have a compensation of the renal function, obtaining a continuous clearance, resembling the function of a healthy kidney as closely as possible. In order for a hemodialysis treatment to have better results compensating for residual renal function, consecutive and longer sessions should be established, however this is a complicated issue depending on the availability of time and tolerance of the patient.

AGRADECIMIENTO: Dr. Cesar Igor Vásconez Vaca, su pérdida fue tan rápida y repentina que nos ha conmovido profundamente y resulta muy difícil resignarse a ello, pero fue un privilegio ser espectadores de su vida, de su habilidad profesional y de sus valores éticos y humanos.

Un eterno agradecimiento por haber compartido sus conocimientos médicos, científicos, investigativos y personales con nosotros. Gracias por haber sido el ser humano que influyó en nuestra formación profesional y en nuestra vida, y seguirá en nuestras memorias para siempre. 